\title{
Short-term spider community monitoring after cattle removal in grazed grassland
}

\author{
Guilherme O. da Silva ${ }^{1,2}$ \& Ricardo Ott
}

\begin{abstract}
1. Seção de Zoologia de Invertebrados, Museu de Ciências Naturais, Fundação Zoobotânica do Rio Grande do Sul. Rua Dr Salvador França, 1427, $90690-000$ Porto Alegre, RS, Brazil. (guilhermeoyarzaba@@gmail.com)

2. Programa de Pós-Graduação em Biologia Animal, Departamento de Zoologia, Instituto de Biociências, Universidade Federal do Rio Grande do Sul. Av. Bento Gonçalves, 9500, 91509-900 Porto Alegre, RS, Brazil.
\end{abstract}

Received 3 January 2017

Accepted 21 June 2017

DOI: 10.1590/1678-4766e2017033

\begin{abstract}
At the Pampa Biome, grazing, like others disturbances, affects fauna and flora, creating heterogeneity in the environment. Little is known about how the diversity and richness of arthropods change during this impact. To improve the knowledge of how spider diversity is affected by grazing, experiments were realized at Pampa. The hypothesis is that abundance of spider will be different when comparing grazed and ungrazed areas. A paired block, with two areas of one hectare each, was established in three areas in the Environmental Protection Area of Ibirapuitã (APA Ibirapuitã), state of Rio Grande do Sul, Brazil. One of these hectares was closed with fences, excluding the catle grazing, in August of 2012. Samplings were realized in November of 2011, 2012 and 2013 using Pitfall traps filled with formol 4\% and disposed in an "X" format in each area. For statistical analyses, T test, ANOSIM, ANOVA and Rarefaction were performed. A total of 1,315 spiders were captured, comprising 77 species or morphospecies belonging to 20 families. The family most abundant was Lycosidae followed by Hahniidae, Linyphiidae and Theridiidae. Linyphiidae was the richest family with 14 species or morphospecies identified. All spiders, adults and juveniles, only adults in species and morphospecies, and most abundant species were used as models for statistics. These models revealed no significant difference between grazed and ungrazed areas after three and 15 months of cattle exclusion.
\end{abstract}

KEYWORDS. Neotropical, Pampa, diversity, Araneae.

RESUMO. Monitoramento de curto prazo da comunidade de aranhas após a remoção do gado em campos pastejados. No Pampa, o pastejo, como outros distúrbios, afeta a fauna e a flora, proporcionando uma maior heterogeneidade no ambiente. Pouco se sabe como a diversidade e a riqueza de artrópodes muda durante este impacto. Para aprimorar o conhecimento de como a diversidade de aranhas é afetada pelo pastejo, experimentos foram realizados no Pampa. A hipótese é que a abundância de aranhas será diferente quando áreas pastejadas e sem pastejo são comparadas. Um bloco de duas parcelas, cada uma com um hectare, foi estabelecido em três fazendas na APA (Área de Proteção Ambiental) do Ibirapuitã, Rio Grande do Sul, Brasil. Um destes hectares foi fechado com cercas, excluindo o pastejo do gado, em agosto de 2012. As amostragens foram realizadas em novembro de 2011, 2012 e 2013 usando armadilhas de queda preenchidas com formol 4\% e dispostas em formato de "X" em cada hectare. Foram utilizados para análise estatística Teste T, ANOSIM, ANOVA e Rarefação. Um total de 1.315 aranhas foi amostrado, compreendendo 77 espécies ou morfoespécies de 20 familias. A família mais abundante foi Lycosidae, seguida de Hahniidae, Linyphiidae e Theridiidae. Linyphiidae foi a família mais rica, com 14 espécies ou morfoespécies identificadas. A soma das abundâncias de aranhas jovens e adultas, a abundância de apenas aranhas adultas e a abundância total somente das espécies mais abundantes foram utilizadas como modelos estatísticos. Estes modelos não revelaram diferença significativa entre áreas com e sem pastejo mesmo após três ou 15 meses de exclusão do gado.

PALAVRAS-CHAVE. Neotropical, Pampa, diversidade, Araneae.

The Pampa is a Neotropical region biome localized in meridional South America, including south Brazil, Uruguay and part of Argentina, covering 750,000 $\mathrm{km}^{2}$ (VÉLEZ et al., 2009; ANDRADE et al., 2015) (Fig. 1). It is composed originally by areas with grasslands and meadows (BEHLING et al., 2009) and according to Köppen-Geiger classification, the climate is considered as "Cfa" (humid temperate with hot summers; KотTEK et al., 2006). In conformity to Suertegaray \& Silva (2009), the Pampa is located in the Southern Temperate Zone with four well-characterized seasons and has a maximum altitude of $200 \mathrm{~m}$.

The human presence in this region began around 10,000 (BP) with pre-Columbian cultures (SUERTEGARAY \&
SILVA, 2009). In general it is not exactly know how the Pampa was before more than some 300 years ago, when disturbance increases dramatically after the European colonization due cattle introduction, uncontrolled fire management, farming and silvicultural activities (SuERTEGARAY \& Silva, 2009; RoDrigues et al., 2010; PODGAISKI et al., 2014; FERRANDO et al., 2016). Considering theses disturbances, many components of the biota, as also the invertebrate fauna, should be directly affected. However, these fauna and its level of endemism are poorly known for this region (LEWINSOHN, 2006), and the enhancement of studies on biodiversity and biogeography of insects, arachnids, crustaceans as for other invertebrates groups are still necessary (BENCKE, 2009). 
Spiders are the second richest group of Arachnida, counting with more than 46,000 valid species distributed in 4,059 genera and 112 families (World Spider Catalog, 2017). The official number of spiders for Brazil is unknown but they could easily reach more than 4,000 species (BRESCOVIT, 1999; BresCovit et al., 2011). For Rio Grande do Sul state, spider richness reach 808 species (BUCKUP et al., 2010). In terms of grasslands, richness and abundance of spider vary. For African grassland, Ammoxenidae, Lycosidae and Salticidae seems to be the most abundant (JANSEN et al., 2013; HADDAD et al., 2015; Foord et al., 2016) as Gnaphosidae, Salticidae and Thomisidae were the richest (FoORD et al., 2011; HADDAD et al., 2015; FoORD \& DipPeNAAR-SCHOEMAN, 2016) in most recent studies. For South American grasslands Linyphiidae, Lycosidae and Salticidae seems to be the most abundant and richest families (RodRIGUES et al., 2010; PoMPOZZI et al., 2011; Podgaiski et al., 2013; CUNHA et al., 2015; ZANETTI, 2016). However, spider diversity is still poorly known at Pampa (Oliveira et al., 2017).

Spiders have their diversity dependent of many factors (FoELIX, 2011): vegetal structure (BALDISSERA et al., 2004; NogueiRa \& PINTO-DA-Rocha, 2016), capacity of dispersal and settlement (Rodrigues et al., 2009; Lin et al., 2016) being distance insignificant (HoRvátH et al., 2009), prey availability and competitive exclusion (DeNNIS et al., 2015;
RODRIGUEZ-ARTIGAS et al., 2016). Moreover, spider are still capable of consume high biomass rate (NYFELLER, 2000; Отт, 2016), are generalist predators in different trophic levels, even eating other spiders (WISE, 2006) and occupying nearly all terrestrial territories (FoELIX, 2011), making up great ecological models (Craig et al., 2001; Foelix, 2011). Their resilience in rapidly reoccupy impacted environmental (Podgaiski et al., 2013), would be a great model for testing the absence of cattle graze impact.

The objective of this work is to present a list of families, species or morphoespecies of ground dwelling spider of Pampa biome. Moreover, to compare the areneofauna in areas with and without cattle graze after three and 15 months of total exclusion of this impact at Pampa. The hypothesis is that abundance of spiders will be different when comparing grazed and ungrazed areas.

\section{MATERIAL AND METHODS}

Study site. The experiments were carried out at Ibirapuitã River Environmental Protection Area "Área de Proteção Ambiental - APA do Ibirapuitã" located at Western Pampas Areas of Rio Grande do Sul state, Brazil (Fig. 1). Six plots of one hectare each, located at three different farms in the municipality of Sant'Ana do Livramento and georeferenced

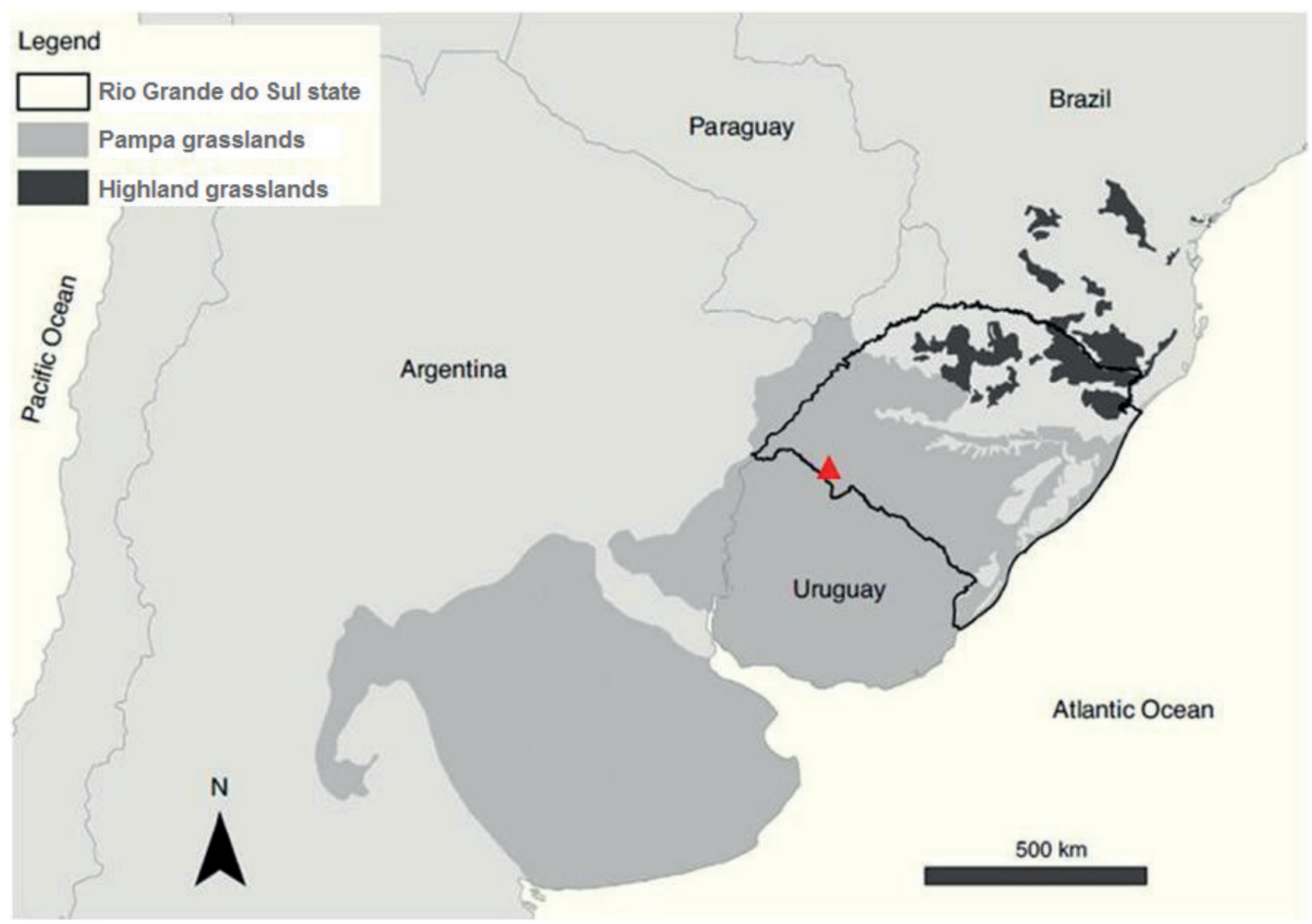

Fig. 1. Extension of the Pampa Biome at Neotropical region. Red triangle indicates APA Ibirapuitã's localization, state of Rio Grande do Sul, Brazil. Map from ANDRADE et al., 2015. 
at 30²8'50.57"S, 55³3'10.21"W ("Estância do Açude"; Farm 1), 30²8'54.97”S, 55³4'14.05”W (“Fazenda Rincão dos Moraes"; Farm 2) and 30²5'54.78”S, 55³8’39.75”W ("Fazenda Bela Vista"; Farm 3) were selected for the sampling. In each farm a block of two plots placed close to $200 \mathrm{~m}$ far from each other were established, being one of them closed with fences in August of 2012, excluding totally the cattle grazing access; the second plot was defined only by poles placed at its corners and the cattle was allowed to free grazing access in the area. Closed plots without grazing were defined herein as ungrazed areas (T1, T2 and T3) and plots with free cattle grazing access were defined as grazed areas $(\mathrm{C} 1, \mathrm{C} 2$ and $\mathrm{C} 3)$.

Data collection. The plots were sampled using pitfall traps made by ordinary plastic cups of $500 \mathrm{ml}$ (15 cm depth, $10 \mathrm{~cm}$ diameter) inserted into a $10 \mathrm{~cm}$ diameter PVC guide. Twelve traps were installed disposed in " $\mathrm{X}$ " format from corner to corner of each plot (72 in total). To measure possible border effects, the traps were separated in three different groups of four traps regarding the distance to the border (edge, middle and center). Traps were placed around $20 \mathrm{~m}$ apart from each other and at least $10 \mathrm{~m}$ from the fence or border line of each plot (Fig. 2). Sampling periods occur in three different years: 8 to 15 November 2011 (no fences), 8 to 16 November 2012 (three months fences enclosure) and 26 November to 3 December 2013 (15 months fence enclosure), fulfilling 1,512 trap days. Traps were filled around 1/3 of total volume with formol at $4 \%$ concentration with some drops of liquid soap to break superficial tension.

Data analysis. Spiders collected at samples were sorted out manually and placed in vials containing $80 \%$ ethanol and after examined using a stereomicroscope. For determination in the lowest possible taxonomic level, dichotomous key were used for families (DIPPENAARSchoemann \& Jocqué, 1997; Brescovit et al., 2002) and papers, available on-line at NMBE World Spider Catalog (World Spider Catalog, 2017), for genera and species. The classification used is also based in the same catalog above; families, genera and species are listed in alphabetic order. Adult and juveniles were sorted by family level and only adult spiders were identified at morphospecies and species level. All adult spiders were deposited at the aracnological collection of "Museu de Ciências Naturais da Fundação Zoobotânica do Rio Grande do Sul” (MCN), Porto Alegre, Brazil.

Most abundant species were defined by their dominance, as those making up $\geq 2 \%$ of the total of all individuals (adapted from SPILLER \& SCHORNER, 1998; Petcharad et al., 2016). For posterior analysis, these species were separated in three ways: (i) most abundant species in general, with abundance of all individuals of 2011, 2012 and 2013; (ii) most abundant species with abundance of all individuals of 2012 and 2013, for testing grazed and ungrazed areas differences; and (iii) most abundant species after 15 months of enclosure, with only abundance of all individuals of 2013, for testing border effect.

For statistical analysis, Student's tests were performed to compare differences in abundance between grazed and ungrazed areas using as models all spiders, only adults in species/morphospecies and the most abundant species. Three categories of tests were applied with these models: (i) sum of 2012 and 2013 abundance; (ii) only 2012 abundance to test three months of enclosure in ungrazed areas; and (iii) only 2013 abundance to test 15 months of enclosure in ungrazed areas. Analysis of similarities (ANOSIM) was performed based in Morisita, Bray-Curtis and Jaccard measures. Abundance of families in 2013, all spiders, only adults in species/morphospecies and most abundant species were used as models to test difference between pitfall groups in ungrazed areas. Analysis of variance (ANOVA) was performed to test differences between pitfall groups in 2013 using medians of abundance of all spiders, only adults in species/morphospecies and most abundant species. Rarefaction curves were performed to plot spider richness in ungrazed areas through the years using ANOVA for testing significance. All statistical analyses were made using Past (Paleontological Statistics 3.13, Hammer et al., 2001). The significance level utilized was $\mathrm{p}<0.05$.

\section{RESULTS}

A total of 1,315 spiders ( 775 adults, 576 males, 199 females; 540 juveniles) were sampled, 685 in grazed areas and 630 in ungrazed areas. Twenty six families were registered, considering juveniles and adults individuals; 77 species or morphospecies of 20 families were identified, of these, 33 nominal species, 33 morphospecies at genera level and 11 morphospecies at only family level (Tab. I). Most abundant families were Lycosidae (433 individuals), Hahniidae (359), Linyphiidae (143), Theridiidae (94). Hahniidae followed by Lycosidae, Linyphiidae and Theridiidae were the most abundant families in ungrazed areas. Lycosidae followed by Hahniidae, Linyphiidae and Theridiidae were the most abundant in grazed areas. Adults in grazed areas sum 360 individuals (271 males; 89 females) and in ungrazed areas sum 415 individuals (305 males; 110 females) (Tab. I).

Linyphiidae was the richest family (14 species or morphospecies), followed by Lycosidae (13), Gnaphosidae (9), Salticidae (8) and Theridiidae (8) (Tab. I). Amphinectidae, Anyphaenidae, Araneidae, Caponiidae, Ctenidae, Miturgidae, Nemesiidae, Oonopidae, Oxyopidae, Phrurolithidae and Tetragnathidae were represented by only one species or morphospecies (Tab. I). Only juveniles of Microstigmatidae, Philodromidae, Pholcidae, Sparassidae and Tengelidae were sampled. Anyphaenidae, Philodromidae, Pholcidae, Tetragnathidae and Trechaleidae were exclusively found in ungrazed areas. Caponiidae, Microstigmatidae, Oxyopidae, Sparassidae and Tengelidae were exclusively recorded in grazed areas.

The most abundant species in general represent $34 \%$ of the total of spiders. They were Neohania sp. 1 (186 individuals), Neohania sp. 2 (155), Guaraniella mahnerti Baert, 1984 (45), Agyneta sp. 2 (35), Schizocosa malitiosa 


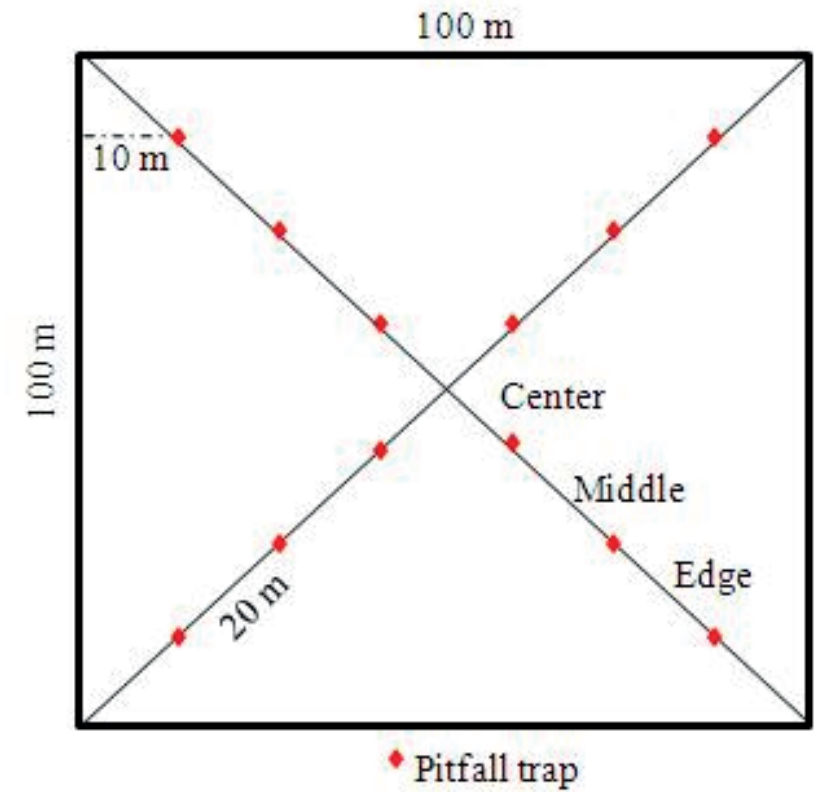

Fig. 2. Format used for exposal of pitfall traps in APA Ibirapuitã, state of Rio Grande do Sul, Brazil during the campaign of 2011, 2012 and 2013. Red diamonds indicates the places of the traps. Traps were placed around $20 \mathrm{~m}$ from each other and least $10 \mathrm{~m}$ from the fence or border of each plot.

(Tullgren, 1905) (30). Twenty-six species are exclusively from ungrazed areas and 14 from grazed areas. Twenty-seven species were singletons and 13 were doubletons.

In 2012 and 2013, 918 spiders were sampled. Of these, the most abundant species represent $33 \%$ of total spiders: Neohania sp. 1 (104 individuals), Neohania sp. 2 (96), G. mahnerti (31), S. malitiosa (25), Agyneta sp. 2 (24) and Birabenia sp. 1 (21). In only 2012, 459 spiders were sampled. Of these, the most abundant species represent $31 \%$ of total spiders and were Neohania sp. 2 (63), Neohania sp. 1 (33), S. malitiosa (22), G. mahnerti (19), Agyneta sp. 2 (8). A total of 459 spiders were sampled only in 2013; the most abundant species represent $39 \%$ of total spiders: Neohania sp. 1 (71), Neohania sp. 2 (33), Agyneta sp. 2 (16), Birabenia sp. 1 (15), Erigone sp. 1 (12), G. mahnerti (12), Semiopyla cataphracta Simon, 1901 (11) and Lycosa thorelli (Keyserling, 1877) (10).

Students' test revealed no significant difference between grazed and ungrazed areas regarding all spiders in 2012 and 2013 ( $\mathrm{p}=0.8047)$, only 2012 with three months of enclosure $(\mathrm{p}=0.7888)$ and 2013 with 15 months of enclosure $(p=0.8413)$. The test wasn't significant different regarding just adults in species/morphospecies in 2012 and 2013 ( $\mathrm{p}=$ $0.4782)$, in just 2012 ( $\mathrm{p}=0.2807)$ and in $2013(\mathrm{p}=0.8465)$. Also, most abundant species weren't significant different in the same parameters 2012 and $2013(\mathrm{p}=0.5744)$, only 2012 $(p=0.2086)$ and just $2013(p=0.7550)$.

Regarding the distance of the traps to the border of ungrazed areas, the Analysis of Similarity (ANOSIM) revealed no significant difference for families (Morisita: $\mathrm{R}=0.0036, \mathrm{p}=0.4095$; Bray-Curtis: $\mathrm{R}=0.0060, \mathrm{p}=0.3943$;
Jaccard: $\mathrm{R}=0.0064, \mathrm{p}=0.3923$ ), all spiders (Morisita: $\mathrm{R}=$ $-0.0519, \mathrm{p}=0.9174$; Bray-Curtis: $\mathrm{R}=-0.0322, \mathrm{p}=0.7674$; Jaccard: $\mathrm{R}=-0.0427, \mathrm{p}=0.8608$ ), only adults in species/ morphospecies (Morisita: $\mathrm{R}=-0.0298 \mathrm{p}=0.7978$; Bray-Curtis: $\mathrm{R}=-0.0073 \mathrm{p}=0.5322$; Jaccard: $\mathrm{R}=-0.0210, \mathrm{p}=0.7046)$ and most abundant species (Morisita: $\mathrm{R}=-0.0379, \mathrm{p}=0.8833$; Bray-Curtis: $\mathrm{R}=-0.0400, \mathrm{p}=0.8508$; Jaccard: $\mathrm{R}=-0.0361$, $\mathrm{p}=0.8694$ ) between pitfall groups in 2013 .

The Analysis of Variance (ANOVA) based in the means of spiders abundance demonstrated no significant difference between pitfall groups in 2013 when all spiders $(p=$ $0.6737)$, only adults in species/morphospecies $(p=0.7392)$ and most abundant species $(\mathrm{p}=0.7365)$ were used as models.

Regarding the rarefaction curves a higher richness was presented in $\mathrm{T} 1$ than in $\mathrm{T} 3$ and $\mathrm{T} 2$ (Fig. 3) through years. However, ANOVA reveled no significant difference between ungrazed areas $(\mathrm{p}=0.08305)$.

\section{DISCUSSION}

Comparing our species list with that of Uruguay (CAPOCASAle, 1990) (144 species and morphospecies), Argiope argentata (Fabricius, 1775), Caponina notabilis (Mello-Leitão, 1939), L. thorelli, Metaltella simoni Keyserling, 1878, S. malitiosa and Teminius insularis (Lucas, 1857) are shared between both lists. For Brazil, São Paulo state has registered 875 species, with just eight species in our list: A. argentata, Camillina pulchra (Keyserling, 1891), Lycosa erythrognatha Lucas, 1836, L. thorelli, Oxyopes salticus Hentz, 1845, Parabatinga brevipes (Keyserling, 1891), S. cataphracta and T. insularis (BRESCOVIT et al., 2011). Of the 808 species recorded for Rio Grande do Sul state (BucKup et al., 2010), 19 species are shared with our list: A. argentata, C. notabilis, C. pulchra, Castianeira chrysura Mello-Leitão, 1943, Castianeira gaucha Mello-Leitão, 1943, Eilica obscura (Keyserling, 1891), Eilica trilineata (Mello-Leitão, 1941), Euryopis camis Levi, 1963, Euryopis spinifera Mello-Leitão, 1944, Glenognatha lacteovittata (Mello-Leitão, 1944), G. mahnerti, L. erythrognatha, L. thorelli, M. simoni, P. brevipes, Psilocymbium lineatum (Millidge, 1991), S. malitiosa, O. salticus and T. insularis. A. argentata, $L$. thorelli and $T$. insularis were present in all lists, and can be considered species with very broad range distribution. Moreover, the low quantity of common species in all lists indicates that composition of spider fauna can be very variable even comparing close regions.

Our data suggest that grazed and ungrazed areas are still very similar in terms of abundance and species composition of ground spiders, even 15 months after the removal of the cattle. However, the findings presented here could be affected by at last two sample design negative effects as stressed below. First, considering the size of the ungrazed areas (just one hectare) added to the fact that our fenced areas are all surrounded by grazed areas, could cause a presumable edge effect over the entire ungrazed areas (MURCIA, 1995; RODRIGUES et al., 2014). Second, the reduced quantity of traps, it size or total trapping days, in other words the reduced 
Tab. I. Ground spider species of Pampa biome, Rio Grande do Sul, southern Brazil. Species listed here are from November (Nov) of 2011, 2012, 2013. Taxa are separate in families, genera and species. Numbers indicate the quantity of adult individuals.

\begin{tabular}{|c|c|c|c|c|c|c|c|}
\hline \multirow[b]{2}{*}{ Taxa } & \multicolumn{3}{|c|}{ Grazed } & \multicolumn{3}{|c|}{ Ungrazed } & \multirow{2}{*}{ Tota } \\
\hline & Nov-11 & Nov-12 & Nov-13 & Nov-11 & Nov-12 & Nov-13 & \\
\hline \multicolumn{8}{|l|}{ Amphinectidae } \\
\hline Metaltella simoni Keyserling, 1878 & 3 & 4 & 1 & 1 & 2 & 5 & 16 \\
\hline \multicolumn{8}{|l|}{ Anyphaenidae } \\
\hline Arachosia sp. & 0 & 0 & 0 & 0 & 1 & 1 & 2 \\
\hline \multicolumn{8}{|l|}{ Araneidae } \\
\hline Argiope argentata (Fabricius, 1775) & 0 & 0 & 0 & 0 & 0 & 2 & 2 \\
\hline \multicolumn{8}{|l|}{ Caponiidae } \\
\hline Caponina notabilis (Mello-Leitão, 1939) & 1 & 0 & 0 & 0 & 0 & 0 & 1 \\
\hline \multicolumn{8}{|l|}{ Corinnidae } \\
\hline Castianeira chrysura Mello-Leitão, 1943 & 0 & 1 & 0 & 0 & 1 & 0 & 2 \\
\hline Castianeira gaucha Mello-Leitão, 1943 & 0 & 1 & 0 & 0 & 0 & 0 & 1 \\
\hline Castianeira sp. 1 & 1 & 0 & 0 & 0 & 0 & 0 & 1 \\
\hline Castianeira sp. 2 & 2 & 1 & 0 & 2 & 6 & 0 & 11 \\
\hline Mazax sp. & 0 & 0 & 0 & 0 & 2 & 0 & 2 \\
\hline \multicolumn{8}{|l|}{ Ctenidae } \\
\hline Parabatinga brevipes (Keyserling, 1891) & 0 & 0 & 0 & 0 & 0 & 1 & 1 \\
\hline \multicolumn{8}{|l|}{ Gnaphosidae } \\
\hline Apopyllus sp. & 0 & 0 & 0 & 0 & 2 & 0 & 2 \\
\hline Camillina galianoae Platnick \& Murphy, 1987 & 1 & 0 & 0 & 0 & 1 & 3 & 5 \\
\hline Camillina pulchra (Keyserling, 1891) & 0 & 3 & 0 & 0 & 1 & 0 & 4 \\
\hline Camillina sp. & 1 & 1 & 0 & 1 & 0 & 0 & 3 \\
\hline Eilica obscura (Keyserling, 1891) & 0 & 0 & 1 & 0 & 0 & 0 & 1 \\
\hline Eilica aff. trilineata & 0 & 0 & 0 & 1 & 1 & 0 & 2 \\
\hline Eilica trilineata (Mello-Leitão, 1941) & 0 & 1 & 0 & 0 & 0 & 0 & 1 \\
\hline Gen? sp. & 1 & 1 & 0 & 0 & 1 & 0 & 3 \\
\hline Neodrassex ibirapuita Ott, 2013 & 0 & 0 & 0 & 0 & 0 & 1 & 1 \\
\hline \multicolumn{8}{|l|}{ Hahniidae } \\
\hline Intihuatana sp. & 0 & 1 & 0 & 0 & 0 & 0 & 1 \\
\hline Neohania sp. 1 & 37 & 8 & 51 & 45 & 25 & 20 & 186 \\
\hline Neohania sp. 2 & 32 & 14 & 17 & 27 & 49 & 16 & 155 \\
\hline \multicolumn{8}{|l|}{ Linyphiidae } \\
\hline Agyneta sp. 1 & 0 & 0 & 0 & 0 & 1 & 2 & 3 \\
\hline Agyneta sp. 2 & 5 & 0 & 5 & 6 & 8 & 11 & 35 \\
\hline Erigone sp.1 & 9 & 2 & 9 & 1 & 1 & 3 & 25 \\
\hline Laminacauda sp. 1 & 0 & 0 & 1 & 0 & 0 & 0 & 1 \\
\hline Moyosi sp. 1 & 3 & 1 & 1 & 1 & 0 & 3 & 9 \\
\hline Neomaso sp. 2 & 2 & 1 & 2 & 1 & 1 & 4 & 11 \\
\hline Neomaso sp. 3 & 0 & 0 & 1 & 1 & 0 & 1 & 3 \\
\hline Pseudotyphistes sp. 2 & 0 & 0 & 1 & 0 & 0 & 0 & 1 \\
\hline Psilocymbium lineatum (Millidge, 1991) & 1 & 0 & 0 & 0 & 0 & 0 & 1 \\
\hline Sphecozone sp. 2 & 1 & 0 & 0 & 1 & 0 & 0 & 2 \\
\hline Tutaibo aff. phoeniceus & 1 & 1 & 0 & 1 & 1 & 0 & 4 \\
\hline Tutaibo sp. 1 & 3 & 0 & 0 & 3 & 4 & 3 & 13 \\
\hline Tutaibo sp. 2 & 2 & 0 & 0 & 0 & 0 & 0 & 2 \\
\hline Tutaibo sp. 3 & 0 & 0 & 1 & 0 & 0 & 0 & 1 \\
\hline Lycosidae & 0 & 0 & 0 & 0 & 0 & 0 & 0 \\
\hline Agalenocosa sp. & 0 & 0 & 0 & 0 & 0 & 1 & 1 \\
\hline Allocosa sp. & 0 & 0 & 0 & 0 & 0 & 1 & 1 \\
\hline Birabenia sp. 1 & 0 & 2 & 1 & 0 & 4 & 14 & 21 \\
\hline Birabenia vittata (Mello-Leitão, 1945) & 0 & 0 & 0 & 0 & 1 & 1 & 2 \\
\hline Gen? sp. 1 & 0 & 1 & 0 & 0 & 0 & 0 & 1 \\
\hline Gen? sp. 2 & 1 & 1 & 3 & 1 & 1 & 4 & 11 \\
\hline Hogna bivittata (Mello-Leitão, 1939) & 3 & 3 & 0 & 2 & 0 & 1 & 9 \\
\hline Lobizon humilis (Mello-Leitão, 1944) & 0 & 0 & 0 & 0 & 1 & 4 & 5 \\
\hline Lycosa erythrognatha Lucas, 1836 & 2 & 0 & 3 & 0 & 2 & 0 & 7 \\
\hline Lycosa thorelli (Keyserling, 1877) & 0 & 2 & 9 & 0 & 3 & 1 & 15 \\
\hline
\end{tabular}


Tab. I. Cont.

\begin{tabular}{|c|c|c|c|c|c|c|c|}
\hline \multirow[b]{2}{*}{ Taxa } & \multicolumn{3}{|c|}{ Grazed } & \multicolumn{3}{|c|}{ Ungrazed } & \multirow{2}{*}{ Total } \\
\hline & Nov-11 & Nov-12 & Nov-13 & Nov-11 & Nov-12 & Nov-13 & \\
\hline Navira naguan Piancentini \& Grismado, 2009 & 0 & 1 & 1 & 0 & 0 & 1 & 3 \\
\hline Schizocosa malitiosa (Tullgren, 1905) & 2 & 15 & 3 & 3 & 7 & 0 & 30 \\
\hline Trochosa sp. & 0 & 0 & 0 & 0 & 1 & 1 & 2 \\
\hline \multicolumn{8}{|l|}{ Miturgidae } \\
\hline Teminius insularis (Lucas, 1857) & 1 & 1 & 4 & 1 & 0 & 2 & 9 \\
\hline \multicolumn{8}{|l|}{ Nemesiidae } \\
\hline Pycnothele sp. 1 & 0 & 4 & 0 & 0 & 2 & 0 & 6 \\
\hline Pycnothele sp. 2 & 0 & 0 & 0 & 1 & 0 & 0 & 1 \\
\hline \multicolumn{8}{|l|}{ Oonopidae } \\
\hline Neotrops aff. tucumanus & 2 & 2 & 0 & 0 & 1 & 1 & 6 \\
\hline \multicolumn{8}{|l|}{ Oxyopidae } \\
\hline Oxyopes salticus Hentz, 1845 & 1 & 0 & 0 & 0 & 0 & 0 & 1 \\
\hline \multicolumn{8}{|l|}{ Phrurolithidae } \\
\hline Orthobula sp. & 0 & 2 & 1 & 2 & 1 & 6 & 12 \\
\hline \multicolumn{8}{|l|}{ Salticidae } \\
\hline aff. Phiale sp. & 0 & 0 & 0 & 0 & 0 & 1 & 1 \\
\hline Gen? sp. 1 & 0 & 0 & 0 & 0 & 0 & 1 & 1 \\
\hline Gen? sp. 2 & 0 & 0 & 0 & 0 & 1 & 0 & 1 \\
\hline Gen? sp. 3 & 0 & 0 & 0 & 1 & 0 & 0 & 1 \\
\hline Gen? sp. 4 & 0 & 0 & 0 & 1 & 0 & 0 & 1 \\
\hline Neonella minuta Galiano, 1965 & 1 & 1 & 1 & 0 & 0 & 1 & 4 \\
\hline Neonella montana Galiano, 1988 & 0 & 0 & 1 & 0 & 1 & 0 & 2 \\
\hline Semiopyla cataphracta Simon, 1901 & 2 & 0 & 0 & 1 & 1 & 11 & 15 \\
\hline \multicolumn{8}{|l|}{ Tetragnathidae } \\
\hline Glenognatha lacteovittata (Mello-Leitão, 1944) & 0 & 0 & 0 & 0 & 0 & 7 & 7 \\
\hline \multicolumn{8}{|l|}{ Theridiidae } \\
\hline Episinus sp.1 & 0 & 1 & 0 & 0 & 0 & 0 & 1 \\
\hline Euryopis camis Levi, 1963 & 0 & 1 & 1 & 1 & 1 & 0 & 4 \\
\hline Euryopis sp. 1 & 0 & 0 & 0 & 0 & 1 & 0 & 1 \\
\hline Euryopis sp. 2 & 3 & 1 & 4 & 0 & 1 & 0 & 9 \\
\hline Euryopis spinifera (Mello-Leitão, 1944) & 1 & 3 & 4 & 0 & 1 & 0 & 9 \\
\hline Guaraniella mahnerti Baert, 1984 & 9 & 7 & 6 & 5 & 12 & 6 & 45 \\
\hline Styposis selis Levi, 1964 & 0 & 0 & 0 & 0 & 1 & 4 & 5 \\
\hline Thymoites piratini Rodrigues \& Brescovit, 2015 & 0 & 0 & 0 & 1 & 1 & 0 & 2 \\
\hline \multicolumn{8}{|l|}{ Thomisidae } \\
\hline Gen? sp. 1 & 0 & 0 & 0 & 1 & 0 & 0 & 1 \\
\hline Gen? sp. 2 & 0 & 1 & 0 & 0 & 1 & 0 & 2 \\
\hline Gen? sp. 3 & 0 & 0 & 3 & 0 & 0 & 1 & 4 \\
\hline \multicolumn{8}{|l|}{ Trachelidae } \\
\hline Gen? sp. 1 & 0 & 0 & 0 & 0 & 0 & 1 & 1 \\
\hline Meriola sp. & 0 & 0 & 0 & 0 & 0 & 1 & 1 \\
\hline Total & 134 & 90 & 136 & 113 & 154 & 148 & 775 \\
\hline
\end{tabular}

"sample effort", could lead to a very low power outcome of statistical tests and therefore no significant difference was found (BRENNAN et al., 1999; Work et al., 2002). However, it is also very likely that in this case, ground spider fauna is not really being affected by grazing, at least in the first 15 months after enclosure and cattle removal.

Due the methodology adopted in this work, the absence of spiders most commonly found in aerial vegetation, like orb-web builders (A. argentata sampled are totally occasional), could be another factor that led us to no significant difference between grazed and ungrazed areas. As spiders' diversity seems to be much correlated to vegetal structure
(Cadenasso \& Pickett, 2001; Souza, 2007; Rodrigues et al., 2010; Gómez et al., 2016; NogueIra \& Pinto-DARосна, 2016), in short time the ground spider fauna seems to be less affected by grazing disturbance. Experiments with fire, where the vegetation is completely burned (PoDGAISKI et al., 2013), demonstrate that web-builders take more time to occupy recent disturbed areas, due its need of tri-dimensional structures for establish a webs (HALAJ et al., 1998; PFISTER et al., 2015; Nogueira \& Pinto-DA-Rocha, 2016). Therefore, aerial vegetation correlated spiders and web-builders, would be more sensitive and respond more strongly to absence of cattle grazing. 


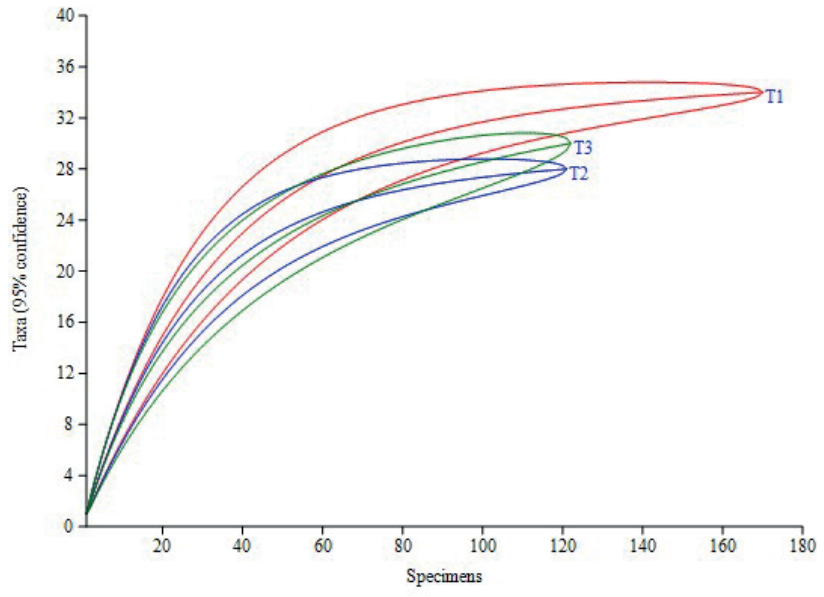

Fig. 3. Richness based rarefaction curves for spiders sampled in ungrazed areas of APA Ibirapuitã, Rio Grande do Sul state, Brazil, trough springs of 2011, 2012 and 2013. Adjacent lines indicates 95\% confidence intervals.

Spiders are usually considered as a useful group to monitory management studies, due to quickly occupancy of altered habitats (UETz et al., 1999) and its important role as predators (Rodrigues et al., 2010; Foelix, 2011; LAWs \& JOERN, 2015); however, ground spiders provide only piece of information (GIBSON et al., 1992). It is very possible that spiders and other invertebrates, such as beetles (GRANDCHAMP et al., 2005; WOODCOK et al., 2005), ants (RED \& ANDERSEN, 2000; CAlCATERRA et al., 2010) and grasshoppers (HaO et al., 2015; FERRANDO et al., 2016) living in the vegetation could respond quicker and intensively to grassland management. Moreover, correlating abundance of these arthropods, would allow a better overview of how the fauna change without grazing perturbation.

Acknowledgements. We thank to the CNPq/PELD Program and "Fundação Zoobotânica do Rio Grande do Sul/Projeto RS Biodiversidade" for grants providing us with fieldwork and laboratory infrastructure support. This work was supported also by CAPES with a scholarship granted to first author (process \#1478689) and is part of his master degree dissertation (PPGBAN/UFRGS).

\section{REFERENCES}

Andrade, B. O.; Kock, C.; Boldrini, I. I.; Vélez-Martin, E.; Hasenack, H.; Hermann, J. M.; Kollmann, J.; Pillar, V. P. \& Overbeck, G. E. 2015. Grassland degradation and restoration: a conceptual framework of stages and thresholds illustrated by southern Brazilian grasslands. Natureza \& Conservação 13(2):95-104.

Baldissera, R.; Ganade, G. \& Fontoura, S. B. 2004. Web spider community response along an edge between pasture and Araucaria forest. Biological Conservation 118:403-409.

Behling, H.; Jeske-Pieruschka, V.; Schüler, L. \& Pillar, V. P. 2009. Dinâmica dos campos no sul do Brasil durante o Quaternário Tardio. In: Pillar, V. P.; Müller, S. C.; Castilhos, Z. M. S. \& Jacques, A. V. A. eds. Campos sulinos: conservação e uso sustentável da biodiversidade. Brasília, Ministério do Meio Ambiente, p. 13-25.

Bencke, G. A. 2009. Diversidade e conservação da fauna dos Campos do Sul do Brasil. In: Pillar, V. P.; Müller, S. C.; Castilhos, Z. M. S. \& JACQUES, A. V. A. Campos sulinos: conservação e uso sustentável da biodiversidade. Brasília, Ministério do Meio Ambiente, p. 101-121.
Brennan, K. E. C.; Majer, J. D. \& Reygaert, N. 1999. Determination of an optimal pitfall trap size for sampling spiders in a Western Australian Jarrah forest. Journal of Insect Conservation 3:297-307.

Brescovit, A. D.; Oliveira, U. \& Santos, A. J. 2011. Spiders (Araneae, Arachnida) from São Paulo State, Brazil: diversity, sampling efforts, and state-of-art. Biota Neotropica 11(1):1-32.

Brescovit, A. D.; Rheims, C. A. \& Bonaldo, A. B. 2002. Araneomorphae - Chave de identificação para famílias de aranhas brasileiras. Available at $<$ http://pt.scribd.com/doc/123853696/Chave-de-Familiasde-Aranhas $>$. Accessed on 19 May 2016.

Brescovit, A. D. 1999. Araneae. In: Joly, C. A. \& Bicudo, C. E. M. orgs. Biodiversidade do Estado de São Paulo, Brasil: síntese do conhecimento ao final do século XX: Invertebrados Terrestres. São Paulo, FAPESP, v. 5, p. 47-56.

Buckup, E. H.; Marques, M. A. L.; Rodrigues, E. N. L. \& Ott, R. 2010 Lista das espécies de aranhas (Arachnida, Araneae) do estado do Rio Grande do Sul, Brasil. Iheringia, Série Zoologia 100(4):483-518.

Cadenasso, M. L. \& Pickett, S. 2001. Effect of edge structure on the flux of species into forest interiors. Conservation Biology 15(1):91-97.

Calcaterra, L. A.; Cabrera, S. M.; Cuezzo, F.; Perez, I. J. \& Briano, J. A. 2010. Habitat and grazing influence on terrestrial ants in subtropical grasslands and savannas of Argentina. Entomological Society of America 103(4):635-646.

CAPocasale, R. M. 1990. An annotated checklist of Uruguayan spiders. Aracnología 11:1-23.

Craig, C. L.; Wolf, S. G.; Davis, J. L. D.; Hauber, M. E. \& Maas, J. L. 2001. Signal polymorphism in the web-decorating spider Argiope argentata is correlated with reduced survivorship and the presence of stingless bees, its primary prey. Evolution 55(5):986-993.

Cunha, J. A. S.; ANDrade, E. B.; Silva, P. R. R. \& Barros, R. F. B. 2015. Araneofauna (Arachnida, Araneae) in conventional and organic crops of watermelon (Citrullus lanatus) in northeastern Brazil. Revista Colombiana de Entomología 41(1):68-75.

Dennis, P.; Skartveit, J.; Kunaver, A. \& McCracken, D. I. 2015. The response of spider (Araneae) assemblages to structural heterogeneity and prey abundance in sub-montane vegetation modified by conservation grazing. Global Ecology and Conservation 3:715-728.

DippenaAr-Schoeman, A. S. \& Jocqué, R. 1997. African Spiders: An Identification Manual. Pretoria, Plant Protection Research Institute Handbook. 391p.

Ferrando, C. P. R.; Podgaiski, L. R.; Costa, M. K. M. \& MendonÇA, JR. M. DE S. 2016. Taxonomic and Functional Resilience of Grasshoppers (Orthoptera, Caelifera) to Fire in South Brazilian Grasslands. Neotropical Entomology 45:374-381.

Foelix, R. F. 2011. Biology of Spiders. Oxford, Oxford University Press. $423 p$.

Foord, S. H. \& Dippenaar-Schoeman, A. S. 2016. The effect of elevation and time on mountain spider diversity: a view of two aspects in the Cederberg mountains of South Africa. Journal of Biogeography 43:2354-2365

Foord, S. H.; Dippenaar-Schoeman, A. S.; Haddad, C. R.; Lotz, L. N. \& LyLE, R. 2011. The faunistic diversity of spiders (Arachnida: Araneae) of the Savanna Biome in South Africa. Transactions of the Royal Society of South Africa 66:170-201.

Foord, S. H.; DippenaAR-Schoeman, A. S.; Jocqué, R.; Haddad, C. R.; Lyle, R. \& Webb, P. 2016. South African National Survey of Arachnida: A checklist of the spiders (Arachnida, Araneae) of the Lekgalameetse Nature Reserve, Limpopo province, South Africa. Koedoe 58(1): 1405-1413.

Gibson, C. W. D.; Hambler, C. \& Brown, V. K. 1992. Changes in spider (Araneae) assemblages in relation to succession and grazing management. Journal of Applied Ecology 29:132-142.

GómeZ, J. E.; LOHMILLER, J. \& JOERN, A. Importance of vegetation structure to the assembly of an aerial web-building spider community in North American open grassland. The Journal of Arachnology 44(1):28-35.

Grandchamp, A. C.; Bergamini, A.; Stofer, S.; Niemela, J.; Duelli, P. \& SCHEIDEGGER, C. 2005. The influence of grassland management on ground beetles (Carabidae, Coleoptera) in Swiss montane meadows. Agriculture, Ecosystems and Environment 110:307-317. 
Haddad, C. R.; Foord, S. H.; Fourie, R. \& DippenaAR-Schoeman, A. S 2015. Effects of fast-burning spring fire on the ground-dwelling spider assemblages (Arachnida: Araneae) in a central South Africa grassland habitat. African Zoology 50(4):281-292.

Halaj, J; Ross, D. W. \& Moldenkel, A. R. 1998. Habitat structure and prey availability as predictors of the abundance and community organization of spiders in Western Oregon forest canopies. The Journal of Arachnology 26:203-220.

Hammer, Ø.; Harper, D. A. T. \& RyAn, P. D. 2001. PAST: Paleontological Statistics package for education and data analysis. Paleontologia Eletronica 4(1):1-9.

Hao, S.; Wang, S.; Cease, A. \& Kang, L. 2015. Landscape level patterns of grasshopper communities in Inner Mongolia: interactive effects of livestock grazing and a precipitation gradient. Landscape Ecology 30:1657-1668

Horváth, R.; Magura, T.; Szinetár, C. \& Tóthemérész, B. 2009. Spiders are not less diverse in small and isolated grasslands, but less diverse in overgrazed grasslands: A field study (East Hungary, Nyérség). Agriculture, Ecosystems and Environment 130:16-22.

Jansen, R.; Makaka, L.; Little, I. T. \& Dippenaar-Schoeman, A. S. 2013. Response of ground-dwelling spider assemblages (Arachnida, Araneae) to montane grassland management practices in South Africa. Journal of Insect Conservation 6:572-589.

Kottek, M.; Griser, J.; Beck, C.; Rudolf, B. \& Rubel, F. 2006. World map of the Köppen-Geiger climate classification updated. Meteorologische Zeitschrift 15:259-263.

Laws, A. N. \& Joern, A. 2015. Predator-prey interactions are context dependent in a grassland plant-grasshopper-wolf spider food chain. Environmental Entomology 44(3):519-528.

Lewinsohn, T. M. 2006. Avaliação do estado do conhecimento da biodiversidade brasileira. Brasília, Ministério do Meio Ambiente. Série Biodiversidade. 520p.

LIN, S.; VASSEUR, L. M. \& You, S. 2016. Seasonal variability in spider assemblages in traditional and transgenic rice fields. Environmental Entomology 45(2):537-546.

MurCIA, C. 1995. Edge effect in fragmented forests: implications for conservation. Trends in Ecology and Evolution 10:58-62.

Nogueira, A. A. \& Pinto-DA-Rocha, R. 2016. The effects of habitat size and quality on the orb-weaving spider guild (Arachnida: Araneae) in an Atlantic Forest fragmented landscape. The Journal of Arachnology 44:36-45.

NYFELLER, M. 2000. Ecological impact of spiders predation: a critical assessment of Britowe's and Tunbull's estimates. Bulletin of the British Arachnological Society 11:367-373.

Oliveira, U.; Brescovit, A. D. \& Santos, A. J. 2017. Sampling effort and species richness assessment: a case study on Brazilian spiders. Biodiversity and Conservation 26(6): 1481-1493

Oтt, R. 2016. Invertebrados terrestres. Natureza em Revista 14:46-47.

Petcharad, B.; Miyashita, T.; Gale, G. A.; Sotthibandhu, S. \& BumRUNGSRI, S. 2016. Spatial patterns and environmental determinants of community composition of web-building spiders in understory across edges between rubber plantations and forests. The Journal of Arachnology 44:182-193.

Pfister, S. C.; Schäfer, R. B.; Schirmel, J. \& Entling, M. H. 2015. Effects of hedgerows and riparian margins on aerial web-building spiders in cereal fields. The Journal of Arachnology 43:400-405.

Podgaiski, L. R.; Goldas, C. S.; Ferrando, C. P. R.; Silveira, F. S.; Joner, F.; Overbeck, G. E.; Mendonça Jr., M. De S. \& Pillar, V. D. 2014. Burning effects on detritivory and litter decay in Campos grasslands. Austral Ecology 39:686-695.
Podgaiski, L. R.; Joner, F.; Lavorel, S.; Moretti, M.; Ibanez, S.; MendonÇA, Jr. M. DE S. \& Pillar, V. D. 2013. Spider trait assembly patterns and resilience under fire-induced vegetation change in south Brazilian Grasslands. PLoS ONE 8(3):1-11.

Pompozzi, G. A.; Tizón, F. R. \& PelaÉz, D. V. 2011. Effects of different frequencies of fire on an epigeal spider community in Southern Caldenal, Argentina. Zoological Studies 50(6):718-724

ReD, J. L. \& Andersen, A. N. 2000. The value of ants as early warning bioindicators: responses to pulsed cattle grazing at an Australian arid zone locality. Journal of Arid Environments 45:231-251.

Rodrigues, E. N. L.; MendonçA Jr., M. de S. \& Costa-Schimidt, L. E. 2014. Spider diversity responds strongly to edge effects but weakly to vegetation structure in riparian forests of Southern Brazil. ArthropodPlant Interactions 8:123-133.

Rodrigues, E. N. L.; MendonçA, JR., M. de S. \& Ott, R. 2009. Spider diversity in a rice agroecosystem and adjacent areas in southern Brazil. Revista Colombiana de Entomología 35:78-86.

Rodrigues, E. N. L.; Rosado, J. L. O. \& Loeck, A. E. 2010. Soil spiders in differing environments: Eucalyptus plantations and grasslands in the Pampa biome, southern Brazil. Revista Colombiana de Entomología 36(2):277-284

Rodriguez-Artigas, S. M.; Ballester, R. \& CorroncA, J. A. 2016. Factors that influence the beta-diversity of spider communities in northwestern Argentinean Grasslands. PeerJ 4:19-46.

SouzA, A. L. T. 2007. Influência da estrutura do habitat na abundância e diversidade de aranhas. In: GonZaGA, M. O.; SANTOS, A. J. \& JAPYASsú, H. F. eds. Ecologia e comportamento de aranhas. Rio de Janeiro, Editora Interciência, p. 25-44.

Spiller, D. A. \& Schoener, T. W. 1998. Lizard reduce spider species richness by excluding rare species. Ecology 79:503-516.

Suertegaray, D. M. A. \& Silva, L. A. P. 2009. Tchê Pampa: histórias da natureza gaúcha. In: Pillar, V. P.; Müller S. C.; Castilhos Z. M. S. \& JACQUES A. V. A. Campos sulinos: conservação e uso sustentável da biodiversidade. Brasília, Ministério do Meio Ambiente, p. 42-59.

Uetz, G. W.; Halaj, J. \& CADY, A. B. 1999. Guild structure of spiders in major crops. The Journal of Arachnology 27:270-280.

Vélez, E.; Chomenko, L.; Schaffer, W. \& Madeira, M. 2009. Um panorama sobre as iniciativas de conservação dos Campos Sulinos. In: Pillar, V. P.; Müller, S. C.; Castilhos, Z. M. S. \& Jacques, A. V. A. eds. Campos sulinos: conservação e uso sustentável da biodiversidade. Brasília, Ministério do Meio Ambiente, p. 356-379.

WisE, D. H. 2006. Cannibalism, food limitation, intraspecific competition, and the regulation of spider populations. Annual Review of Entomology 51:441-65.

Wise, D. H. 1993. Spiders in ecological webs. The Journal of Arachnology 23:48-50.

Woodcock, B. A.; Pywell R. F.; Roy, D. B.; Rose R. J. \& Bell, D. 2005. Grazing management of calcareous grasslands and its implications for the conservation of beetle communities. Biological Conservation 125:193-202.

Work, T. T.; Buddle, C. M.; Korinus, L. M. \& Spence, J. R. 2002. Pitfall trap size and capture of three taxa of litter-dwelling arthropods: implications for biodiversity studies. Entomological Society of America 31(3):438-448.

World Spider Catalog. 2017. World Spider Catalog, version 18.0. Natural History Museum Bern. Available at $<$ http://www.wsc.nmbe.ch/>. Accessed on 12 June 2017.

ZAnetTi, N. I. 2016. Records of epigeal spiders in Bahía Blanca in the temperate region of Argentina. Acta Zoológica Mexicana 32(1):32-44. 